PNNL-17909

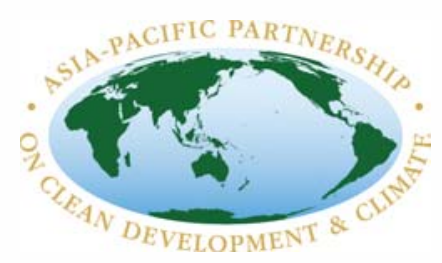

\title{
Country Report on Building Energy Codes in China
}

\author{
B Shui \\ M Evans \\ $\mathrm{H}$ Lin (CABR) \\ W Jiang \\ B Liu \\ Bo Song (CABR) \\ $S$ Somasundaram
}

April 2009

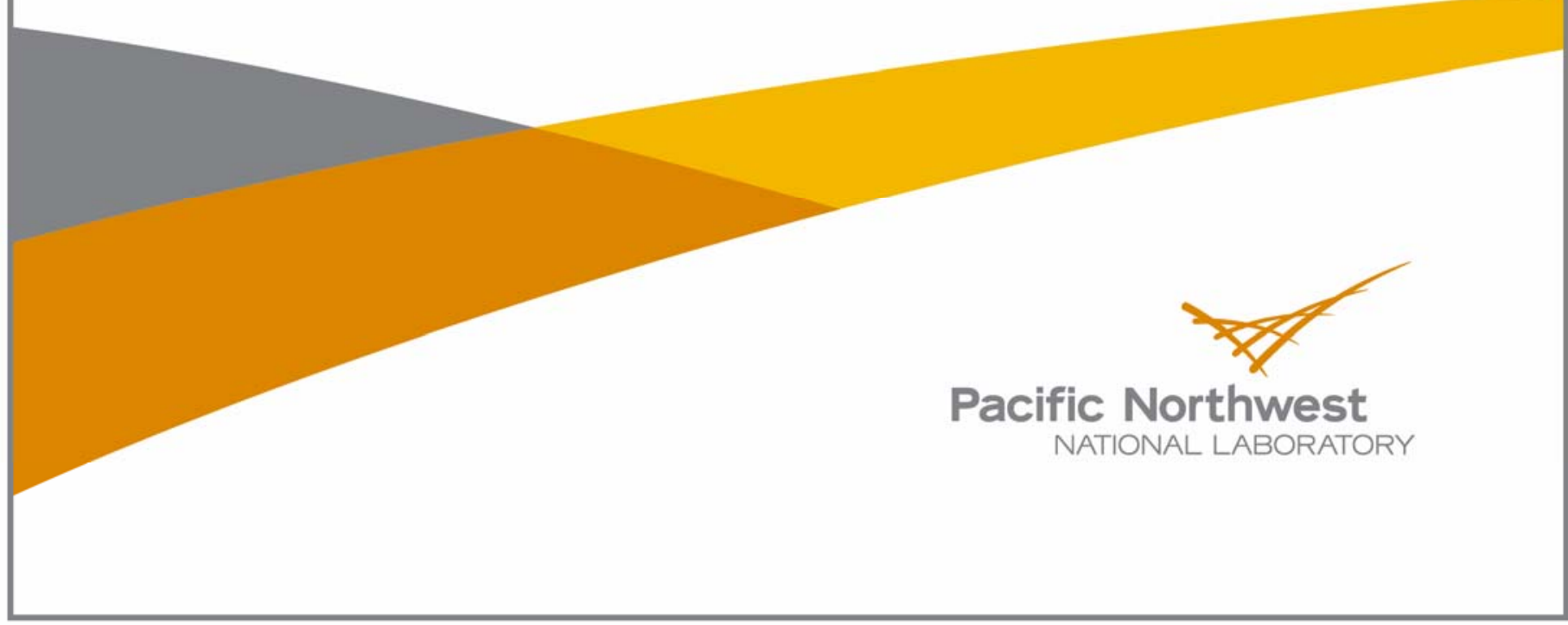




\title{
DISCLAIMER
}

This report was prepared as an account of work sponsored by an agency of the United States Government. Neither the United States Government nor any agency thereof, nor Battelle Memorial Institute, nor any of their employees, makes any warranty, express or implied, or assumes any legal liability or responsibility for the accuracy, completeness, or usefulness of any information, apparatus, product, or process disclosed, or represents that its use would not infringe privately owned rights. Reference herein to any specific commercial product, process, or service by trade name, trademark, manufacturer, or otherwise does not necessarily constitute or imply its endorsement, recommendation, or favoring by the United States Government or any agency thereof, or Battelle Memorial Institute. The views and opinions of authors expressed herein do not necessarily state or reflect those of the United States Government or any agency thereof.

\author{
PACIFIC NORTHWEST NATIONAL LABORATORY \\ operated by \\ BATTELLE \\ for the \\ UNITED STATES DEPARTMENT OF ENERGY \\ under Contract DE-AC05-76RL01830
}

Printed in the United States of America
Available to DOE and DOE contractors from the Office of Scientific and Technical Information,
P.O. Box 62, Oak Ridge, TN 37831-0062;
ph: (865) 576-8401
fax: $(865)$ 576-5728
email: reports@adonis.osti.gov

\begin{abstract}
Available to the public from the National Technical Information Service, U.S. Department of Commerce, 5285 Port Royal Rd., Springfield, VA 22161 ph: (800) 553-6847 fax: $(703) 605-6900$ email: orders@ntis.fedworld.gov online ordering: http://www.ntis.gov/ordering.htm
\end{abstract}

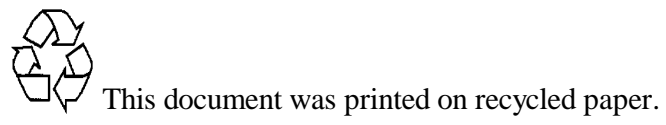


PNNL-17909

\section{Country Report on Building Energy Codes in China}

B Shui

$M$ Evans

$\mathrm{H}$ Lin (CABR)

W Jiang

B Liu

Bo Song (CABR)

$S$ Somasundaram

April 2009 



\section{Foreword}

Buildings account for about $30 \%$ of all energy consumption globally and a significant share of greenhouse gas emissions. Building energy codes help ensure that new buildings use energy efficiently, and this can reduce building energy use by $50 \%$ or more compared to buildings designed without energy efficiency in mind. This is important because buildings typically last 30-50 years, and it is much less expensive and time-consuming to design for energy efficiency than to retrofit a building later. Based on the experience of the Asia-Pacific region, it is clear that building energy codes, when implemented, save energy and improve comfort in new buildings. By design, most building energy codes are cost-effective, saving consumers significant amounts of money on their energy bills.

The Asia-Pacific Partnership on Clean Development and Climate (APP) is a publicprivate collaboration to accelerate the development and deployment of clean energy technologies. APP partners include Australia, Canada, China, India, Japan, Republic of Korea, and the United States (the U.S.). APP countries account for more than half of the global economy, energy consumption and greenhouse gas emissions. APP's Buildings and Appliance Task Force (BATF) provides a forum for APP partners to work together on energy efficiency in buildings and appliances. This report was prepared under the framework of BATF, in particular a BATF project called "Survey building energy codes and Develop Scenarios for reducing energy consumption through energy code enhancement in APP countries" (BATF-06-24).

At the request of the U.S. Department of Energy, the Pacific Northwest National Laboratory's Joint Global Change Research Institute has prepared a series of reports surveying building energy codes in the seven APP countries. These reports include country reports on building energy codes in each APP partner country and a comparative report based on the country reports. This particular report is the country report on building energy codes in China. 


\section{Acknowledgements}

This report owes its existence to the Asia-Pacific Partnership on Clean Development and Climate. We would like to thank all the APP partner countries and experts who collaborated on this project. We are particularly grateful to Dr. Seung-Eon Lee at the Korean Institute of Construction Technology for his oversight of the APP project under which this report was prepared (BATF 06-24). We would also like to thank Mark Ginsberg, Jean Boulin and Marc Lafrance from the U.S. Department of Energy for their leadership and financial support of this work.

Diana Shankle, manager of the PNNL Building Energy Codes Program, has provided moral and intellectual support for this project. Mark Halverson reviewed this report. Kate Williams and Alison Delgado provided editorial assistance. We would also like to express our gratitude to several other individuals who supported or participated in the APP building energy code assessment in various capacities including Joe Huang, Bipin Shah, Xinchun (Steven) Wang, Siwei Lang, Xiaojiao Zhu, Elizabeth Malone, Kay Killingstad, Paulette Land and Kim Swieringa. And we would like to acknowledge the Korean Ministry of Knowledge Economy and the Korea Energy Management Corporation which supported the publication of this report. 


\section{Contents}

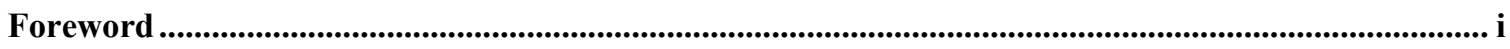

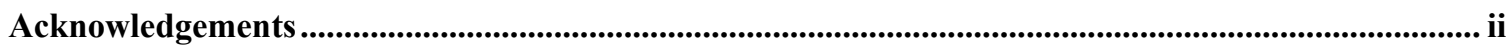

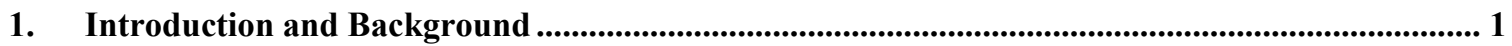

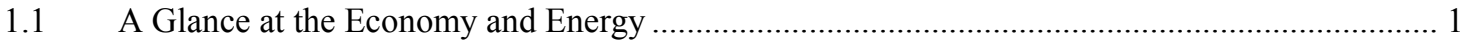

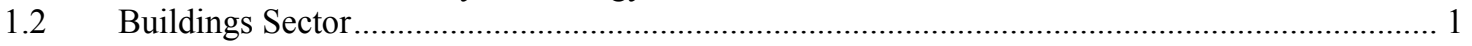

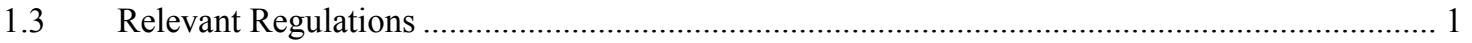

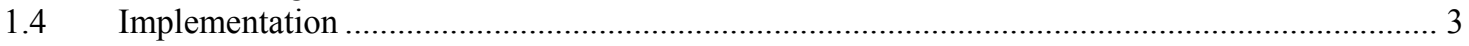

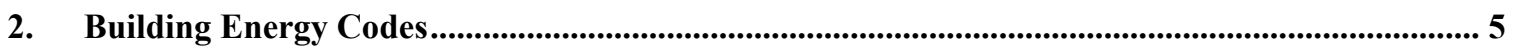

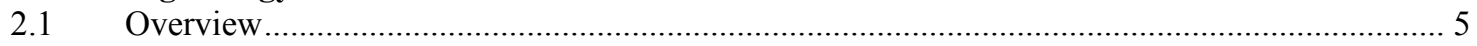

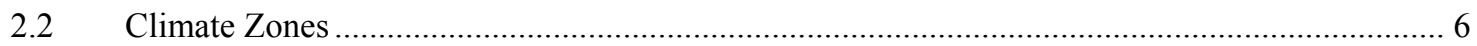

2.3 Design Standard for Energy Efficiency in Public Buildings (2005) .......................................... 7

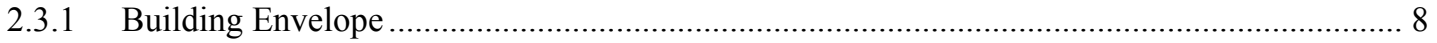

Mandatory Requirements: Prescriptive Requirements .............................................................. 8

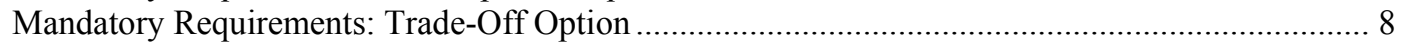

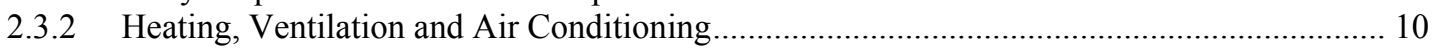

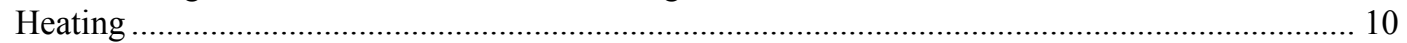

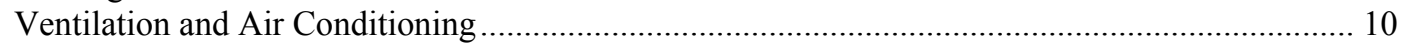

Heating and Cooling Sources for Heating and Air Conditioning Systems ................................... 10

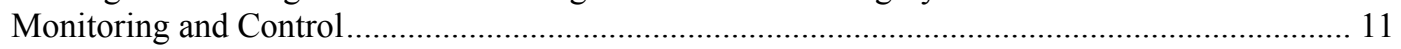

$2.4 \quad$ Design Standard for Energy Efficiency in Residential Buildings ........................................... 11

2.4.1 Energy Conservation Design Standard for Residential Buildings in the Heating Zones (1995,

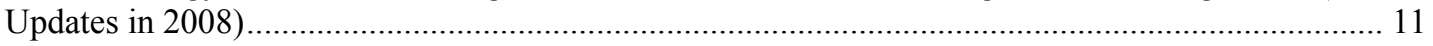

2.4.2 Design Standard for Energy Efficiency in Residential Buildings in the Hot Summer and Cold

Winter Zone (2001, Updates in 2008) ........................................................................................ 13

2.4.3 Design Standard for Energy Efficiency in Residential Buildings in the Hot Summer and

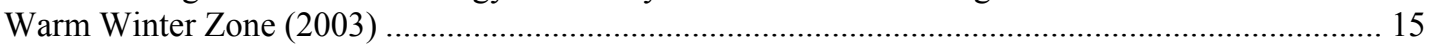

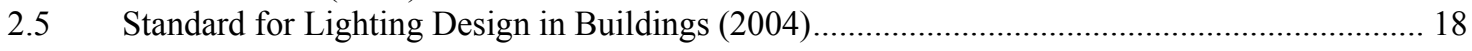

3 Other Developments .............................................................................................................................. 19

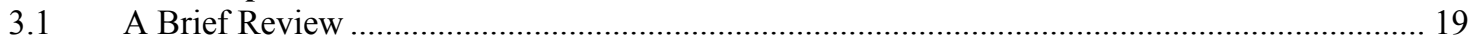

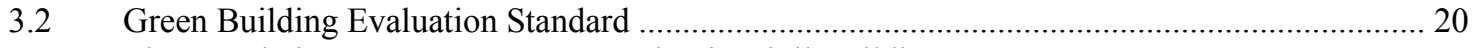

3.3 The Regulations on Energy Conservation in Civil Buildings ................................................... 20

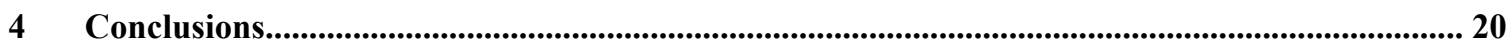

List of Acronyms .................................................................................................................................................. 22

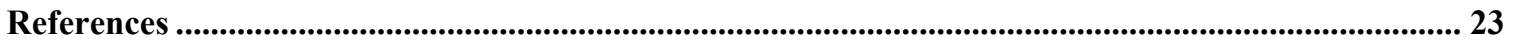

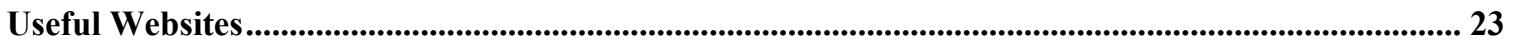




\section{List of Figures}

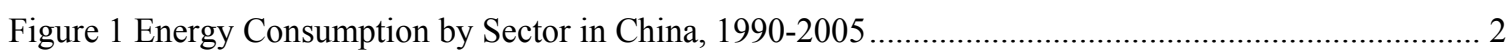

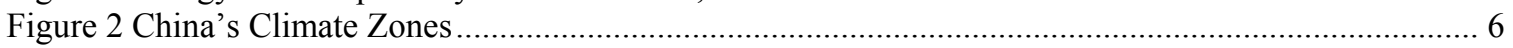

Figure 3 North and South Sub Regions in the Hot Summer and Warm Winter Zone .............................. 16

\section{List of Tables}

Table 1 Mean Temperatures in Architectural Climate Zones.................................................................... 6

Table 2 Essential Features of the Design Standard for Energy Efficiency in Public Buildings (2005)......... 7

Table 3 Maximum Heat Transfer Coefficient or U-factors ................................................................... 9

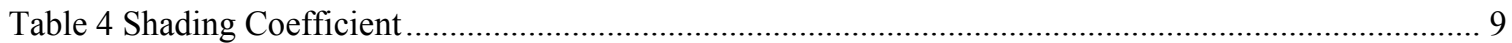

Table 5 Essential Features of the Design Standard for Energy Efficiency in Residential Buildings in the Severe Cold and Cold Zones (1995, Updates in 2008) ................................................................... 12

Table 6 Essential Features of the Design Standard for Energy Efficiency in Residential Buildings in the Hot

Summer and Cold Winter Zone (2001, Updates in 2008).............................................................. 14

Table 7 Essential Features of the Design Standard for Energy Efficiency in Residential Buildings in the Hot

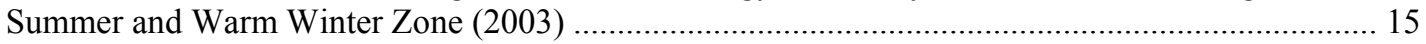

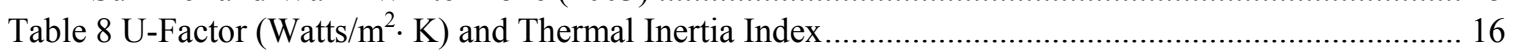

Table 9 U-Factors and Overall Shading Coefficients of Exterior Window in the North Sub Region .......... 17

Table 10 Overall Shading Coefficients of Exterior Windows by Wall Characteristics in the South Sub

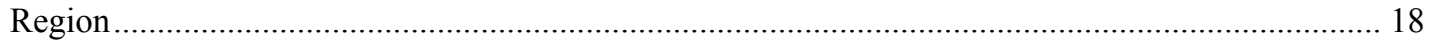

Table 11 Essential Features of the Standard for Lighting Design in Buildings (2004) .............................. 18

Table 12 Maximum Lighting Power Densities for Office Buildings............................................................ 19 


\section{Introduction and Background}

\subsection{A Glance at the Economy and Energy}

With impressive economic growth in the past two decades, China has emerged as one of the largest economies in the world. In 2007, its gross domestic product was US\$3.4 trillion on a nominal basis, though on a purchasing power basis, it was US $\$ 10.2$ trillion (IMF 2008, 2008). China is the second largest energy consumer, behind the United States. Nearly 70\% of its energy consumption is from coal. In 2006, China surpassed the U.S. as the top carbon emitter, with 6,018 Mt of carbon dioxide (EIA 2008).

\subsection{Buildings Sector}

By the end of 2003, existing buildings in China covered 38 billion square meters of floor space, $37 \%$ of which was in urban areas. In recent years, China has been adding 1.8 to 2 billion square meters annually, making it the world's largest market for new construction $(\mathrm{Wu}$ and Liu 2007; $\mathrm{Wu}$ et al. 2007). Among these new buildings, $60 \%$ are residential, $10 \%$ are industrial and $30 \%$ are public or commercial ${ }^{1}$ (Lang 2005).

According to the International Energy Agency, China accounted for 14\% of total global building energy use in 2005. Its buildings sector consumed 373 million tons of oil equivalent (Mtoe) or 34\% of final energy use in 2005 (Figure 1). From 1995-2005, China's residential energy consumption, the world's largest, was around $90 \%$ of its building energy consumption, with $1.1 \%$ annual growth rate. During the same period, the average annual growth rate of its commercial building energy use was 7.7\%, the highest among APP countries (IEA 2007).

\subsection{Relevant Regulations}

Building energy efficiency issues in China have drawn increasing attention from the government since the mid-1980s, when China began its large-scale construction in urban areas (Huang and Deringer 2007). China's first Energy Conservation Law, released in 1997, addressed the importance of building energy codes in one of its fifty Articles. The revised Energy Conservation Law, released in 2007, has a separate Section ${ }^{3}$ on Construction Energy Conservation, which includes seven Articles directly or indirectly related to build energy codes: administrative structure (Article 34), compliance and enforcement of building energy codes (Article 35), releasing energy information when selling houses by real estate development enterprises (Article 36), the implementation of indoor temperature control system in public buildings (Article 37), household heat metering system (Article 38), urban power conservation management for decorative landscape lighting in public facilities and large-scale buildings (Article 39), and building materials, solar and renewable energy (Article

\footnotetext{
${ }^{1}$ This report uses the term "public" buildings in the way the Chinese regulations use it. In practice, this is quite similar to the idea of commercial buildings in other countries. Public buildings in China include government buildings but also other private buildings used for commerce or services. The term "public" buildings in China does not include residential or industrial buildings.

${ }^{2}$ It includes consumption of renewable and waste energy.

3 The sections under Chapter III Rational Use of Energy Conservation include Section 1 General Provisions, Section 2 Industrial Energy Conservation, Section 3 Construction Energy Conservation, Section 4 Transport Energy Conservation, Section 5 Energy Conservation by Public Institutions and Section 6 Energy Conservation by Key Energy Consuming Entities.
} 
40).

Figure 1 Energy Consumption by Sector in China, 1990-2005

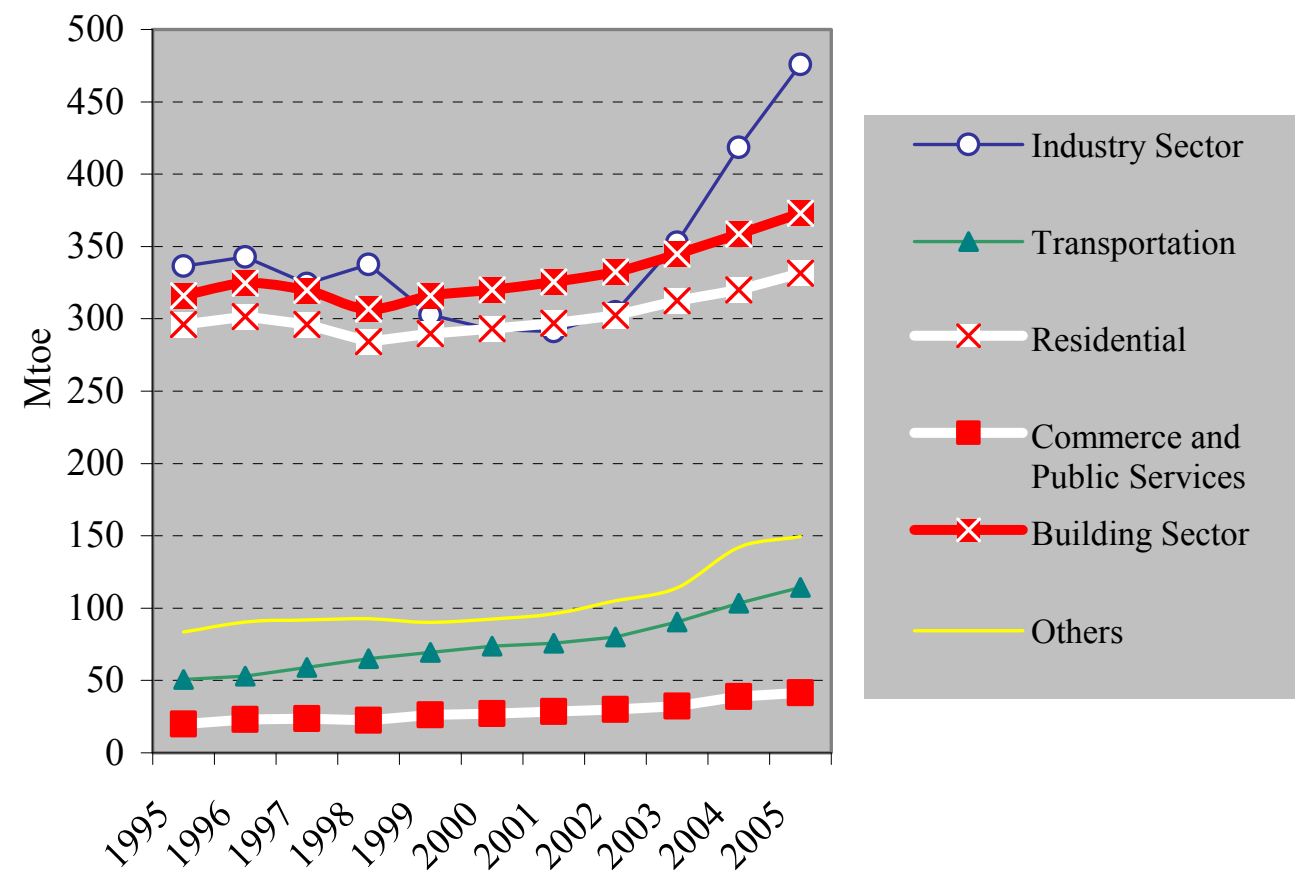

Notes: Energy consumption in this figure refers to final energy use, which includes consumption of renewable and waste energy; the sector "Others" includes agriculture, forestry, fishing, and non-specified and non-energy use.

Source: International Energy Agency, 2007

The National Development and Reform Commission (NDRC), the powerful administrative entity in charge of China's macro economic policies and development, issued the China Medium and Long Term Energy Conservation Plan in 2004. The Plan revealed ambitious energy conservation targets for Chinese buildings: "During the Eleventh Five-year Plan period, new buildings should strictly subject to the design standard of 50\% energy conservation. Several major cities such as Beijing and Tianjin shall take a lead in implementing the $65 \%$ energy-saving standard. Reform of heat supply system shall be carried out in a full scale. In China's large and medium cities, a charge system based on thermal meter will be widely spread in district heating of residential and public buildings; small cities will be pilot of such practice. Energy saving retrofit for existing residential and public buildings shall be conducted in combination with urban reconstruction. Large cities are expected to improve $25 \%$ of building areas, medium cities $15 \%$ and small cities $10 \%$.."

In 2005, the Chinese government called for building a resource conserving and environmentally friendly society in its Eleventh Five-Year Plan. This plan is widely regarded as the roadmap for China's social and economic development for 2006 to 2010. In this newest national plan, ten priority programs related to energy conservation have been identified for meeting the goals of reducing energy intensity and mitigating primary pollutants by $20 \%$ and $10 \%$, respectively, by the year 2010 , compared to the levels in 2005 . Six of the ten priority 
programs are related to building energy efficiency, including (1) energy conservation in buildings, (2) energy efficient lighting, (3) energy conservation in governmental buildings and vehicles, (4) district heating and power generation, (5) recovery of residual heat and pressure, and (6) building the energy conservation monitoring and technological support system.

China has issued a series of national and industrial codes to promote building energy efficiency, including three design standards for residential buildings in different parts of China (published in 1995, 2001, and 2003, respectively) and one design standard for public buildings (2005). In addition, China has developed standards for lighting design in buildings (2004). Energy standards covering other building-related issues include: the technical specifications for the energy efficient renovation of existing residential buildings in the heating zones (2001), the technical code for ground source heat pump systems (2005), the technical code for solar water heating systems in civil buildings ${ }^{4}(2006)$, the standard for energy consumption surveys in civil buildings (2007), and the standard for energy efficiency inspections of buildings (2007). In this country report, building energy codes refer to design standards for public and residential buildings as well as the standards for lighting design.

The Ministry of Housing and Urban-Rural Development (MOHURD, or the former Ministry of Construction) coordinates and develops China's national building energy codes. The China Academy of Building Research (CABR) is the chief developer of nearly all of China's national building energy codes. On behalf of MOHURD, CABR is responsible for explaining and maintaining China's building energy codes.

Local governments can choose to either comply with the national codes or adopt more stringent local codes. Approximately one hundred local design codes primarily based on these national codes are in place across the country (Lang 2005).

In order to improve building energy efficiency, MOHURD set several goals in 2005, including the reduction of energy consumption in new construction by $50 \%$ and the completion of energy conservation retrofits for $25 \%, 15 \%$ and $10 \%$ of the existing buildings in big cities, medium cities and small cities, respectively, by 2010 (MOHURD 2005).

\subsection{Implementation}

MOHURD regulates the building industry in China. Within MOHURD, the Department of Standards and Norms is in charge of the development of building energy standards. The Department of Building Energy Conservation, and Science and Technology, the previous Department of Science and Technology, is responsible for policy development and implementation, research and development, and international collaboration related to building energy efficiency.

Although MOHURD is responsible for directing and supervising code enforcement efforts, day-to-day enforcement is undertaken by city governments through their construction administration departments, which are funded by city government. The construction

\footnotetext{
${ }^{4}$ Civil buildings refer to both residential and public buildings.
} 
administration departments simultaneously report to the city governments and to the provincial branches of MOHURD.

Like in many other countries, the point of control in enforcement of building energy standards is during design and construction.

Since 2005, certified independent organizations (including drawing verification centers and inspection centers) are tasked with reviewing building designs on paper and inspecting buildings for compliance on site. Without the approval of a certified independent drawing verification center, the local construction administration departments will not allow construction to start. If construction has started without approval, the construction administration department will order the builder to suspend construction and make corrections within a specified time limit. If such a project has been completed, the building cannot be sold or used. The local construction administration departments collect all the inspection results and documentation. Article 35 of the 2007 Energy Conservation Law stated the responsibilities of relevant stakeholders, and non-compliance consequences such as the building permit not being issued (see the below Box).

\section{Article 35 of the 2007 Energy Conservation Law}

The construction, design, building and supervision entities of construction projects shall abide by the standards for construction energy conservation.

With respect to construction projects inconsistent with the standards for construction energy conservation, the Construction Administration Departments shall not approve to start the construction thereof; and if any of the projects has been constructed, the department shall order the entity to suspend construction and make correction within a time limit; and if any of the aforesaid projects has been completed, it shall not be sold or used.

The Construction Administration Departments are responsible for strengthening supervision and inspection of the implementation of construction energy conservation standards by

Enforcement of building energy standards has historically been problematic. Expert assessments and some surveys have found that compliance is much better in major cities like Beijing and Shanghai, in the north and in developed regions, while it is less satisfactory in smaller cities and towns, in the south and in less developed regions. Actual enforcement rates vary, and different sources of data provide different estimates. Compliance is also better at the design stage than in actual construction, highlighting the importance of inspections.

Since 2005, MOHURD has conducted an annual inspection-based survey of building energy efficiency and mitigation in key Chinese cities across the country. For example, the 2008 survey involved travel to 55 large Chinese cities, including provincial capitals, four municipalities (such as Beijing and Shanghai), and five sub-provincial cities (such as Ningbo and Qingdao). 
MOHURD usually sends nine to ten survey teams in the fourth quarter of each year. The national survey lasts one month or so. MOHURD sends a notice about the survey to the selected cities two weeks before the survey takes place.

A key component of the survey relates to enforcement of building energy codes. The selected cities are required to provide a complete inventory of the building projects submitted since the last survey. The survey team will randomly inspect twelve projects. Of these, it will examine the building design drawings for six projects (including 4 public building projects and 2 residential building projects). For the remaining six, the survey team will conduct on-site inspections of the construction. Local construction administration departments are scored based on the inspection results, and the scores are sorted from high to low. The work teams will send notices for compliance violations to failed projects. Some provinces, such as Zhejiang, have conducted several provincial surveys on the enforcement of building energy codes annually since 2005.

The release of the Code for Acceptance of Energy Efficient Building Construction, issued by MOHURD in 2007, is also a critical part of governmental regulatory efforts to implement building energy codes in China. The code covers construction quality and acceptance for the building envelope (wall, window, door, roof and floor), heating, HVAC systems, lighting, monitoring and controls. It applies to new construction, and additions and retrofits of existing buildings. The local construction administration department accepts a construction project after it complies with the Code for Acceptance. The certified inspection company verifies compliance through an inspection.

\section{Building Energy Codes}

\subsection{Overview}

The Chinese government has prioritized certain areas of building energy code development, based on relative energy consumption and other factors. For example, code development activities have focused more on residential than public buildings, more on the northern part of China than on the south, and more on new rather than existing buildings (Lin 2008).

China's current building energy standards in both public and residential buildings are mainly focused on the building envelope and HVAC systems, excluding other important building components such as lighting, electric power and hot water systems. In other words, Chinese building energy codes aim to improve the thermal performance of the building envelope and the HVAC energy efficiency--the two factors widely believed to have the greatest influence on building energy efficiency in China (Lin 2008). Lighting is covered in a separate standard.

After introducing the climate zone categories, this section of the report reviews the design standards for public buildings, and the three design standards for residential buildings. This section concludes with an overview of the Standard for Lighting Design in Buildings (2004), which offers code information regarding energy efficient lighting. 


\subsection{Climate Zones}

China's building energy standards identify five climate zones, including (1) severe cold, (2) cold, (3) hot summer and cold winter (HSCW), (4) temperate, and (5) hot summer and warm winter (HSWW), presented in Figure 2 and Table 1.

Figure 2 China's Climate Zones

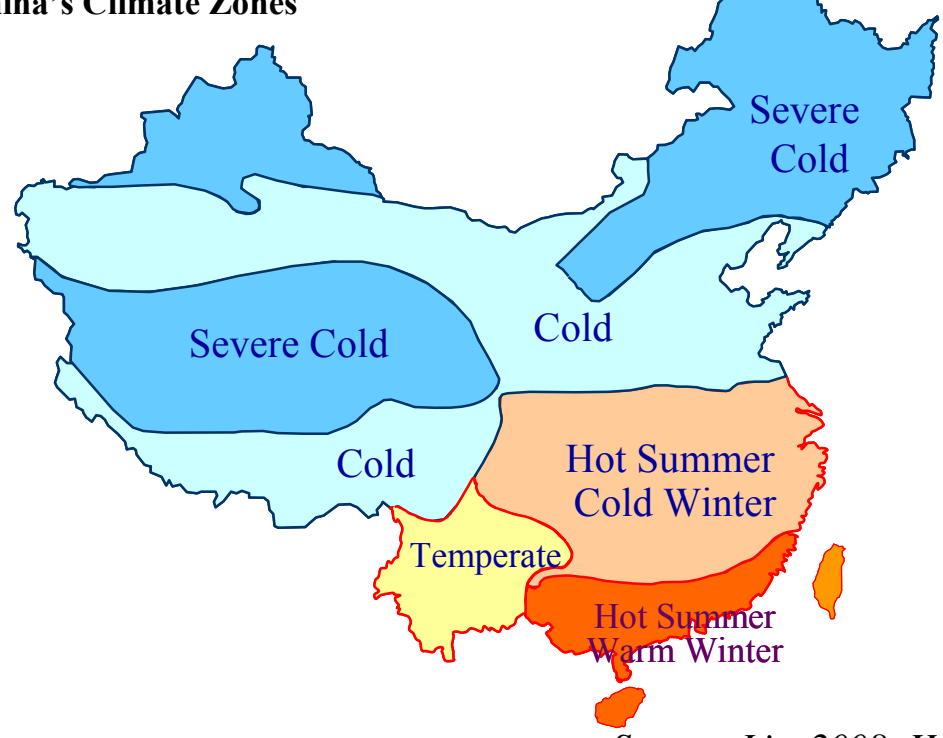

Source: Lin, 2008; Huang and Deringer, 2007

Table 1 Mean Temperatures in Architectural Climate Zones

\begin{tabular}{|l|c|c|c|c|}
\hline \multirow{2}{*}{ Climate Zone } & \multicolumn{2}{|c|}{ Mean Temperature in } & \multicolumn{2}{c|}{} \\
\cline { 2 - 5 } & Coldest Month & Hottest Month & HDD $^{\mathbf{0}} \mathbf{1 8}$ & CDD $^{\mathbf{0}} \mathbf{1 8}$ \\
\hline Severe Cold & $\leq-10{ }^{0} \mathrm{C}$ & & $3800-8000$ & \\
\hline Cold & $-10-0{ }^{0} \mathrm{C}$ & & $2000-3800$ & $100-200$ \\
\hline HSCW & $0-10^{\circ} \mathrm{C}$ & $25-30{ }^{\circ} \mathrm{C}$ & $600-1000$ & $50-300$ \\
\hline HSWW & $>10{ }^{0} \mathrm{C}$ & $25-29{ }^{\circ} \mathrm{C}$ & $\leq 600$ & $>200$ \\
\hline Temperate & $0-13^{\circ} \mathrm{C}$ & $18-25{ }^{\circ} \mathrm{C}$ & $600-2000$ & $\leq 50$ \\
\hline
\end{tabular}

Source: Lin, 2008; Huang and Deringer, 2007

The northern part of China is located in the severe cold and cold zones, where space heating is the predominant end use for buildings. The HSCW zone covers the central part of China, where space heating and cooling are both required for comfort in buildings. The southern part of China, which falls in the HSWW zone, has seen increasing energy demand for cooling during hot summers. 


\subsection{Design Standard for Energy Efficiency in Public Buildings (2005)}

Public buildings, as mentioned in China's building energy standards, refers to non-residential buildings, including commercial, educational and governmental buildings. The first building energy code for public buildings was released in 1993 for tourist hotels, entitled Energy Conservation Design Standard for Building Envelope and Air Conditioning in Tourist Hotels. The current one, aimed at the broad category of public buildings, is called the Design Standard for Energy Efficiency in Public Buildings and was released in 2005.

This standard focuses on the energy efficient design of new construction, additions and retrofits of existing public buildings. The purpose of the standard is to reduce new buildings' annual energy consumption by $50 \%$, compared with buildings of the early $1980 \mathrm{~s}$. The standard addresses the efficiency of the building envelope and HVAC systems with both mandatory ${ }^{5}$ and voluntary provisions. The standard consists of five chapters and three appendices, as summarized in Table 2 .

Table 2 Essential Features of the Design Standard for Energy Efficiency in Public Buildings (2005)

\begin{tabular}{|c|c|}
\hline Section Number and Title & Description \\
\hline 1. General Provisions & Purpose and scope \\
\hline 2. Terminology & Definition of the key terms used this code \\
\hline $\begin{array}{l}\text { 3. Indoor Environment Design Conditions for } \\
\text { Energy Efficient Design }\end{array}$ & $\begin{array}{l}\text { Recommended indoor design temperature, } \\
\text { relative humidity and outside air ventilation } \\
\text { rate }\end{array}$ \\
\hline $\begin{array}{l}\text { 4. Design for Architecture and Building } \\
\text { Thermal Engineering }\end{array}$ & $\begin{array}{l}\text { Mandatory and voluntary provisions and } \\
\text { either prescriptive criteria or trade-off options } \\
\text { related to the building envelope }\end{array}$ \\
\hline 5. Heating, Ventilation and Air Conditioning & $\begin{array}{l}\text { Mandatory and voluntary provisions and } \\
\text { prescriptive criteria related to HVAC, } \\
\text { monitoring and control }\end{array}$ \\
\hline $\begin{array}{l}\text { Appendix A - Building Exterior Shading } \\
\text { Coefficient Calculation Method }\end{array}$ & $\begin{array}{l}\text { Method and equations for calculating building } \\
\text { exterior shading coefficient }\end{array}$ \\
\hline $\begin{array}{l}\text { Appendix B - Building Envelope Tradeoff } \\
\text { Method }\end{array}$ & $\begin{array}{l}\text { Procedure for calculating and comparing } \\
\text { energy consumption for proposed building } \\
\text { design and reference building }\end{array}$ \\
\hline $\begin{array}{l}\text { Appendix C - Cost-Effective Pipe Insulation } \\
\text { Thickness for Cold and Hot Water Loop in } \\
\text { HVAC System }\end{array}$ & $\begin{array}{l}\text { Cost-effective pipe insulation thickness table } \\
\text { for cold and hot water loop in HVAC system }\end{array}$ \\
\hline
\end{tabular}

Source: Design Standard for Energy Efficiency in Public Buildings 2005

${ }^{5}$ See $\S 4.1 .2, \S 4.2 .2, \S 4.2 .4, \S 4.2 .6, \S 5.1 .1, \S 5.4 .2(1,2,3,5,6), \S 5.4 .3, \S 5.4 .5, \S 5.4 .8$ and $\S$ 5.4.9. 


\subsubsection{Building Envelope}

The mandatory requirements for compliance, achieved with either the prescriptive requirements or trade-off options, include requirements for roofs, opaque walls, floors, vertical fenestration and skylights. The standard also covers voluntary requirements for the inside surface temperature of thermal bridges in exterior walls and roofs, exterior window shading, natural ventilation, the operable area of exterior windows and transparent curtain walls, air infiltration and insulation of entry doors, and air tightness of exterior windows and transparent curtain walls.

\section{Mandatory Requirements: Prescriptive Requirements}

The public building standard gives opaque construction requirements in terms of maximum heat transfer coefficients, or U-factors (Table 3), except that the requirements for slab-ongrade and below-grade walls are provided in terms of minimum thermal resistance (R-values). The requirements for slab-on-grade are different between perimeter area and non-perimeter area.

The standard describes vertical fenestration (including transparent curtain wall) requirements in terms of maximum U-factors and shading coefficients (SC) for different orientations (Tables 3 and 4). The window-to-wall ratio (WWR) must not be greater than 0.7 . The minimum visual light transmittance (VLT) of glazing for vertical fenestration must not be less than 0.4 if the WWR is less than 0.4 .

The standard also provides maximum U-factors for skylights (Table 4). In addition, skylights cannot be more than $20 \%$ of the total building roof area.

\section{Mandatory Requirements: Trade-Off Option}

A building envelope complies with the standard if the proposed building design energy use is less than that of the reference building. The trade-off option is similar to the energy cost budget method used in the U.S. standards, such as ASHRAE 90.1. Appendix B of the standard outlines the procedure and calculation assumptions for the envelope trade-off option. 
Table 3 Maximum Heat Transfer Coefficient or U-factors

Unit: watt $/\left(\mathrm{m}^{2} \cdot \mathrm{K}\right)$

\begin{tabular}{|c|c|c|c|c|c|c|c|c|c|}
\hline & \multicolumn{2}{|c|}{ Severe Cold Zone A } & \multicolumn{2}{|c|}{ Severe Cold Zone B } & \multicolumn{2}{|c|}{ Cold Zone } & \multirow{2}{*}{ HSCW } & \multirow{2}{*}{ HSWW } \\
\hline & & $\mathrm{SC} \leq 0.3$ & $0.3<\mathrm{SC} \leq 0.4$ & $\mathrm{SC} \leq 0.3$ & $0.3<\mathrm{SC} \leq 0.4$ & $\mathrm{SC} \leq 0.3$ & $0.3<\mathrm{SC} \leq 0.4$ & & \\
\hline & Roof & $\leqslant 0.35$ & $\leqslant 0.30$ & $\leqslant 0.45$ & $\leqslant 0.35$ & $\leqslant 0.55$ & $\leqslant 0.45$ & $\leqslant 0.70$ & $\leqslant 0.90$ \\
\hline \multicolumn{2}{|c|}{$\begin{array}{l}\text { Exterior wall (including non- } \\
\text { transparent curtain wall) }\end{array}$} & $\leqslant 0.45$ & $\leqslant 0.40$ & $\leqslant 0.50$ & $\leqslant 0.45$ & $\leqslant 0.60$ & $\leqslant 0.50$ & $\leqslant 1.0$ & $\leqslant 1.5$ \\
\hline \multicolumn{2}{|c|}{$\begin{array}{l}\text { Overhead or protruding floor } \\
\text { that contacts outdoor air }\end{array}$} & $\leqslant 0.45$ & $\leqslant 0.40$ & $\leqslant 0.50$ & $\leqslant 0.45$ & $\leqslant 0.60$ & $\leqslant 0.50$ & $\leqslant 1.0$ & $\leqslant 1.5$ \\
\hline \multicolumn{2}{|c|}{$\begin{array}{l}\text { Partition wall or floor of non- } \\
\text { heated and heated rooms }\end{array}$} & $\leqslant 0.6$ & $\leqslant 0.6$ & $\leqslant 0.8$ & $\leqslant 0.8$ & $\leqslant 1.5$ & $\leqslant 1.5$ & N.A. & N.A. \\
\hline \multirow{5}{*}{$\begin{array}{l}\text { Single- } \\
\text { orientation } \\
\text { exterior } \\
\text { windows } \\
\text { (including } \\
\text { transparent } \\
\text { curtain } \\
\text { walls) }\end{array}$} & $\mathrm{WWR} \leq 0.2$ & $\leqslant 3.0$ & $\leqslant 2.7$ & $\leqslant 3.2$ & $\leqslant 2.8$ & $\leqslant 3.5$ & $\leqslant 3.0$ & $\leqslant 4.7$ & $\leqslant 6.5$ \\
\hline & $0.2<\mathrm{WWR} \leq 0.3$ & $\leqslant 2.8$ & $\leqslant 2.5$ & $\leqslant 2.9$ & $\leqslant 2.5$ & $\leqslant 3.0$ & $\leqslant 2.5$ & $\leqslant 3.5$ & $\leqslant 4.7$ \\
\hline & $0.3<\mathrm{WWR} \leq 0.4$ & $\leqslant 2.5$ & $\leqslant 2.2$ & $\leqslant 2.6$ & $\leqslant 2.2$ & $\leqslant 2.7$ & $\leqslant 2.3$ & $\leqslant 3.0$ & $\leqslant 3.5$ \\
\hline & $0.4<\mathrm{WWR} \leq 0.5$ & $\leqslant 2.0$ & $\leqslant 1.7$ & $\leqslant 2.1$ & $\leqslant 1.8$ & $\leqslant 2.3$ & $\leqslant 2.0$ & $\leqslant 2.8$ & $\leqslant 3.0$ \\
\hline & $0.5<\mathrm{WWR} \leq 0.7$ & $\leqslant 1.7$ & $\leqslant 1.5$ & $\leqslant 1.8$ & $\leqslant 1.6$ & $\leqslant 2.0$ & $\leqslant 1.8$ & $\leqslant 2.5$ & $\leqslant 3.0$ \\
\hline \multicolumn{2}{|c|}{ Skylight } & \multicolumn{2}{|c|}{$\leqslant 2.5$} & \multicolumn{2}{|c|}{$\leqslant 2.6$} & $\leqslant 2.7$ & $\leqslant 2.7$ & $\leqslant 3.0$ & $\leqslant 3.5$ \\
\hline
\end{tabular}

\section{Table 4 Shading Coefficient}

\begin{tabular}{|c|l|c|c|c|}
\hline \multicolumn{2}{|c|}{} & Cold Zone & HSCW & HSWW \\
\hline \multirow{3}{*}{$\begin{array}{c}\text { Single-orientation } \\
\text { exterior windows } \\
\text { (including transparent } \\
\text { curtain walls) }\end{array}$} & WWR $\leq 0.2$ & N.A. & N.A. & N.A. \\
\cline { 2 - 5 } & $0.2<\mathrm{WWR} \leq 0.3$ & N.A. & $\leqslant 0.55 /-$ & $\leqslant 0.50 / 0.60$ \\
\cline { 2 - 5 } & $0.3<\mathrm{WWR} \leq 0.4$ & $\leqslant 0.70 /-$ & $\leqslant 0.50 / 0.60$ & $\leqslant 0.45 / 0.55$ \\
\cline { 2 - 5 } & $0.4<\mathrm{WWR} \leq 0.5$ & $\leqslant 0.60 /-$ & $\leqslant 0.45 / 0.55$ & $\leqslant 0.40 / 0.50$ \\
\hline \multicolumn{2}{|c|}{ Skylights } & $\leqslant 0.50 /-$ & $\leqslant 0.40 / 0.50$ & $\leqslant 0.35 / 0.45$ \\
\hline
\end{tabular}

Notes:

When there is an exterior overhang,

shading coefficient is equal to the product of the shading coefficient of the glass and the exterior overhang. When there is no exterior overhang, the shading coefficient is equal to the shading coefficient of glass.

Source: Design Standard for Energy Efficiency in Public Buildings 2005 


\subsubsection{Heating, Ventilation and Air Conditioning}

The code strongly recommends that public buildings in the severe cold zone use hot waterbased district heating, and not forced air systems for winter heating. In the cold zone, the code recommends that public buildings use hot water-based district heating, considering factors like building types, number of heating days, energy consumption and operational costs, and a comprehensive economic and technical analysis.

The public building standard mandates that building designers calculate heating, hourly itemized cooling loads in preparing their designs. New buildings may not use electric boilers and electric water heaters for heating. ${ }^{6}$ There are mandatory requirements for minimum efficiency levels for boilers, ${ }^{7}$ vapor compression chillers and heat pumps, ${ }^{8}$ and airconditioners with capacities greater than $7 \mathrm{~kW} .{ }^{9}$ For absorption chillers, there are also mandatory requirements for performance parameters at various rating conditions. ${ }^{10}$

\section{Heating}

Hot water should be used as the heat source for district heating systems. There are requirements for heating system loop design and layout, installation and design of radiators, and installation of pressure balance devices in water loop branches. For public buildings with tall spaces, radiant heating systems are recommended.

\section{Ventilation and Air Conditioning}

There are requirements and recommendations for selecting air conditioning systems under certain conditions and circumstances. The standard recommends ventilation air rates and control methods for constant air volume systems. ${ }^{11}$ The standard also recommends design strategies for outside air intake systems. Likewise, the standard recommends using demandcontrolled ventilation for spaces with high occupancy density and large occupancy variation. Requirements and recommendations also cover energy recovery ventilation, air filters, water loops, air distribution systems, evaporative cooling, fans, pumps, and insulation thickness for the water loops and ductwork.

\section{Heating and Cooling Sources for Heating and Air Conditioning Systems}

The standard includes recommendations on selecting the plant and equipment for heating and air conditioning systems. The equipment selection should be based on building configuration, characteristics of energy use, local energy resources, pricing structures and environmental regulation. The standard provides six guidelines for the equipment selection, and it also provides requirements for the selection of integrated part-load value (IPLV) for boiler, chiller and heat pump.

\footnotetext{
${ }^{6}$ See $\S 5.4 .2(1,2,3,5$ and 6$)$.

${ }^{7}$ See $\$ 5.4 .3$.

${ }^{8}$ See $\S 5.4 .5$.

${ }^{9}$ See $\$ 5.4 .8$.

${ }^{10}$ See $\$$ 5.4.9.

${ }^{11}$ Or the systems with constant air volume. Please see $\S 5.3 .26$ for details.
} 


\section{Monitoring and Control}

HVAC systems should have monitoring and control equipment. This equipment should include features such as parameter testing, operating condition display, automatic adjustment and control, automatic switch in response to operating conditions, energy metering and central monitoring and a control system. The design standard recommends digital controls for all-air systems in buildings with more than 20,000 square meters of floor space.

\subsection{Design Standard for Energy Efficiency in Residential Buildings}

To date, China has released three national building energy standards for residential buildings. The standards cover different climate zones: the heating zone (or severe cold and cold zones), the HSCS zone and the HSWW zone. These building energy standards focus heavily on the thermal performance requirements for building envelopes and the requirements for HVAC equipment and systems. They include a mixture of prescriptive requirements and performance-based approaches. All three standards apply to the energy efficient design of new construction, additions and retrofit of existing residential buildings.

Since mid-2005, a revised national energy design standard for residential buildings that combines the three previous regional standards had been under development. In September 2006, MOHURD decided to delay its development, and concentrated instead on the revisions in the Design Standard for Energy Efficiency in Residential Buildings in the Severe Cold and Cold Zones (originally called the Energy Conservation Design Standard for Residential Buildings in the Heating Zones), and the Design Standard for Energy Efficiency in Residential Buildings in the Hot Summer and Cold Winter Zone.

\subsubsection{Energy Conservation Design Standard for Residential Buildings in the Heating Zones (1995, Updates in 2008)}

China's first building energy code for residential buildings, entitled the Energy Conservation Design Standard for Residential Buildings in the Heating Zones, was released in 1986, and later revised in 1995. This code was developed for new residential buildings in the severe cold and cold zones. The 1986 and 1995 versions required residential buildings to be approximately $30 \%$ and $50 \%$ more efficient than residential buildings that were built in the early 1980s. In November 2008, a revised version was submitted for review, which targets a $65 \%$ improvement in energy efficiency compared to buildings built in the early 1980s (CABR 2008).

The 1995 standard addresses building envelope and heating systems in five sections and five appendices, while the 2008 version extends to seven appendices, summarized in Table 5. In addition, the 2008 version categorizes the severe cold and cold zones into five sub regions, providing shape coefficients, heat transfer coefficients for roofs and windows, and WWR for the five sub regions. The 2008 version also recommends the use of renewable energy when conditions permit (CABR 2008).

Since the 2008 version is still in the approval process, its specific contents will not be covered by this country report. 
Table 5 Essential Features of the Design Standard for Energy Efficiency in Residential Buildings in the Severe Cold and Cold Zones (1995, Updates in 2008)

\begin{tabular}{|c|c|c|c|}
\hline \multicolumn{2}{|c|}{ The 1995 Standard } & \multicolumn{2}{|c|}{ Updates in 2008} \\
\hline Section Number and Title & Description & Section Number and Title & Updates \\
\hline 1. General Principles & Purpose and scope & 1. General Provisions & \\
\hline 2. Technical Terms & $\begin{array}{l}\text { Definition of the key terms used } \\
\text { in this standard }\end{array}$ & 2. Terminology & \\
\hline $\begin{array}{l}\text { 3. Indices for Heat Loss and Coal } \\
\text { Consumption for Heating }\end{array}$ & $\begin{array}{l}\text { Parameters and equations for } \\
\text { calculating indices of heat loss } \\
\text { and coal consumption for } \\
\text { heating }\end{array}$ & $\begin{array}{l}\text { 3. Sub Regions in the Severe Cold and } \\
\text { Cold Zones, and Indoor Environment } \\
\text { Design Conditions for Energy } \\
\text { Efficiency Design }\end{array}$ & $\begin{array}{l}\text { Definition of sub regions in severe cold } \\
\text { and cold zones, updated indoor } \\
\text { temperatures and air exchange rates for } \\
\text { heating calculations }\end{array}$ \\
\hline $\begin{array}{l}\text { 4. Design for Architecture and } \\
\text { Building Thermal Engineering }\end{array}$ & $\begin{array}{l}\text { U-factors for building envelopes } \\
\text { by outdoor temperature, shape } \\
\text { coefficient, WWR, orientation } \\
\text { and other prescriptive criteria }\end{array}$ & $\begin{array}{l}\text { 4. Thermal Design for Architecture and } \\
\text { Building Envelopes }\end{array}$ & $\begin{array}{l}\text { Updated shape coefficients, and U-factors } \\
\text { for roofs and windows by WWR }\end{array}$ \\
\hline 5. Design for Heating & $\begin{array}{l}\text { Prescriptive criteria for heating } \\
\text { systems (such as boilers and } \\
\text { pumps), and pipe insulation, }\end{array}$ & $\begin{array}{l}\text { 5. Energy Efficiency Design for } \\
\text { Heating, Ventilation and Air } \\
\text { Conditioning }\end{array}$ & $\begin{array}{l}\text { More specifications for calculations and } \\
\text { assessments related to envelope thermal } \\
\text { engineering }\end{array}$ \\
\hline $\begin{array}{l}\text { Appendix A - Parameters and } \\
\text { Indices of Building Heat Loss } \\
\text { and Coal Consumption for } \\
\text { China Major Cities and Towns }\end{array}$ & $\begin{array}{l}\text { Parameters (days, average } \\
\text { outdoor temperatures and degree } \\
\text { days), and indices of building } \\
\text { heating loss and coal } \\
\text { consumption by the main } \\
\text { Chinese cities }\end{array}$ & $\begin{array}{l}\text { Appendix A - Climate Zones, Key } \\
\text { Weather Parameters and Maximum } \\
\text { Energy Consumption in Major Chinese } \\
\text { Cities }\end{array}$ & $\begin{array}{l}65 \% \text { improvement in energy efficiency, } \\
\text { general principles for system design of } \\
\text { heating source, ventilation and air } \\
\text { adjustment }\end{array}$ \\
\hline $\begin{array}{l}\text { Appendix B - Correction Factor } \\
\varepsilon_{\mathrm{i}} \text { for Overall Heat Transfer } \\
\text { Coefficients (U-factors) for } \\
\text { Building Envelopes }\end{array}$ & $\begin{array}{l}\varepsilon_{\mathrm{i}} \text { for building envelopes } \\
\text { (windows, walls and roofs) by } \\
\text { orientation in eight Chinese } \\
\text { cities }\end{array}$ & \multicolumn{2}{|c|}{$\begin{array}{l}\text { Appendix B - Calculation of Average Heat-Transfer Coefficients and Thermal } \\
\text { Bridge U-factors }\end{array}$} \\
\hline \multicolumn{2}{|c|}{$\begin{array}{l}\text { Appendix C-Calculation of Average Heat Transfer Coefficients } \\
\text { of Exterior Walls }\end{array}$} & \multicolumn{2}{|c|}{ Appendix C-Calculation of Ground Heat Transfer Coefficients } \\
\hline \multicolumn{2}{|c|}{ Appendix D - Calculation of Building Area and Volume } & \multicolumn{2}{|c|}{$\begin{array}{l}\text { Appendix D - Correction Factor } \varepsilon_{\mathrm{i}} \text { for Overall Heat Transfer Coefficients (U- } \\
\text { factors) for Building Envelopes }\end{array}$} \\
\hline \multicolumn{2}{|c|}{ Appendix E - Explanation of Terms in this Standard } & \multicolumn{2}{|c|}{ Appendix E - Building Exterior Shading Coefficient Calculation Method } \\
\hline & & \multicolumn{2}{|c|}{ Appendix F - Calculation of Building Area and Volume } \\
\hline & & \multicolumn{2}{|c|}{ Appendix G - Minimal Thickness of the Insulation Layer of Heating Pipe } \\
\hline
\end{tabular}

Source: Design Standard for Energy Efficiency in Residential Buildings in the Severe Cold and Cold Zones 1995, CABR (2008b) 


\subsubsection{Design Standard for Energy Efficiency in Residential Buildings in the Hot Summer and Cold Winter Zone (2001, Updates in 2008)}

With China's soaring economic growth in the 1990s, energy consumption for air conditioning and space heating became a major energy end user in central and south China, which led to a huge increase of residential electricity use (Huang and Deringer 2007). In 2001, the Design Standard for Energy Efficiency in Residential Buildings in the Hot Summer and Cold Winter Zone was issued, followed by the Design Standard for Energy Efficiency in Residential Buildings in the Hot Summer and Warm Winter Zone in 2003 (see 2.4.3). In November 2008, a revised version was submitted for review.

The purpose of the 2001 standard is to reduce the building's annual energy consumption of air conditioning and heating by $50 \%$, compared with buildings without measurement of energy saving. The revised version still aims at the same 50\% reduction as stated in the 2001 standard.

The 2001 standard addresses building envelope and HVAC systems, with mandatory ${ }^{12}$ (such as shape coefficient, U-factors of window) and voluntary provisions (such as the orientation of a building should utilize or be close to the north-south axis, and natural ventilation). The 2001 standard consists of six sections and two appendices, while the reviewed 2008 version extends to three appendices, summarized in Table 6 . The 2008 version also provides system design requirements for geothermal heat pump, and extends the weather data of Chinese cities (CABR 2008)

Since the 2008 version is still in the approval process, its specific contents will not be covered by this country report.

${ }^{12}$ See $\S 3.0 .3, \S 4.0 .3, \S 4.0 .4, \S 4.0 .7, \S 4.0 .11, \S 4.0 .11, \S 6.0 .2$ and $\S 6.0 .6$. 
Table 6 Essential Features of the Design Standard for Energy Efficiency in Residential Buildings in the Hot Summer and Cold Winter Zone (2001, Updates in 2008)

\begin{tabular}{|c|c|c|c|}
\hline \multicolumn{2}{|c|}{ The 2001 Standard } & \multicolumn{2}{|c|}{ Updates in 2008} \\
\hline Section Number and Title & Description & Section Number and Title & Updates \\
\hline 1. General Principles & Purpose and scope & $\begin{array}{l}\text { The same title as the } 2001 \\
\text { standard (henceforth, "The } \\
\text { same") }\end{array}$ & \\
\hline 2. Technical Terms & $\begin{array}{l}\text { Definition of the key terms used in } \\
\text { this code }\end{array}$ & The same & \\
\hline $\begin{array}{l}\text { 3. Design Indices for Indoor } \\
\text { Thermal Environment and } \\
\text { Building Energy Efficiency }\end{array}$ & $\begin{array}{l}\text { Recommended indoor design } \\
\text { temperature and outside air } \\
\text { ventilation rate }\end{array}$ & $\begin{array}{l}\text { 3. Calculation Indices for } \\
\text { Design of Indoor Thermal } \\
\text { Environment }\end{array}$ & $\begin{array}{l}\text { Updated indoor temperatures and air } \\
\text { exchange rates for heating and } \\
\text { cooling calculation. }\end{array}$ \\
\hline $\begin{array}{l}\text { 4. Energy Efficiency Design } \\
\text { for Architecture and } \\
\text { Building Thermal } \\
\text { Engineering }\end{array}$ & $\begin{array}{l}\text { Mandatory and voluntary } \\
\text { provisions related to building } \\
\text { envelope }\end{array}$ & $\begin{array}{l}\text { 4. Thermal Design for } \\
\text { Architecture and Building } \\
\text { envelope }\end{array}$ & $\begin{array}{l}\text { Updated shape coefficients, U-factors } \\
\text { of roof and window by WWR and } \\
\text { orientation }\end{array}$ \\
\hline $\begin{array}{l}\text { 5. Comprehensive Indexes } \\
\text { of Building Energy } \\
\text { Efficiency }\end{array}$ & $\begin{array}{l}\text { Parameters used in the calculation } \\
\text { of whole building energy } \\
\text { conservation index, reference } \\
\text { building }\end{array}$ & $\begin{array}{l}\text { 5. Comprehensive Assessment } \\
\text { for Building Envelope Thermal } \\
\text { Engineering }\end{array}$ & $\begin{array}{l}\text { More specifications for calculation } \\
\text { and assessment related to envelope } \\
\text { thermal engineering }\end{array}$ \\
\hline $\begin{array}{l}\text { 6. Heating, Ventilation and } \\
\text { Air Conditioning Design }\end{array}$ & $\begin{array}{l}\text { Mandatory provisions and } \\
\text { prescriptive criteria }\end{array}$ & The same & $\begin{array}{l}\text { General principles for system design } \\
\text { of cooling source, heating source, } \\
\text { ventilation and air adjustment }\end{array}$ \\
\hline $\begin{array}{l}\text { Appendix A - Calculation } \\
\text { of Average Thermal } \\
\text { Transmission Coefficient of } \\
\text { Envelope Wall }\end{array}$ & $\begin{array}{l}\text { Method and equations for } \\
\text { calculating building exterior } \\
\text { shading coefficient in summer and } \\
\text { winter }\end{array}$ & The same & \\
\hline \multirow{2}{*}{$\begin{array}{l}\text { Appendix B - Calculation } \\
\text { of Area and Volume }\end{array}$} & Calculation equations & The same & \\
\hline & & $\begin{array}{l}\text { Appendix C Simplified } \\
\text { Calculation of Shading } \\
\text { Coefficient }\end{array}$ & \\
\hline
\end{tabular}

Source: Design Standard for Energy Efficiency in Residential Buildings in the Hot Summer and Warm Winter 2003, CABR (2008a) 


\subsubsection{Design Standard for Energy Efficiency in Residential Buildings in the Hot Summer and Warm Winter Zone (2003)}

The Design Standard for Energy Efficiency in Residential Buildings in the Hot Summer and Warm Winter Zone was issued in 2003. It covers the energy efficient design of new construction, additions and retrofits of existing residential buildings in HSWW. The purpose of the standard is to reduce the building's annual energy consumption of air conditioning and heating by $50 \%$, compared with buildings without measurement of energy saving.

The standard addresses building envelope and HVAC systems, with mandatory ${ }^{13}$ (such as thermal transmission coefficient in Tables 8, 9 and 10) and voluntary provisions (such as the orientation of a building should utilize or be close to the north-south axis). The standard consists of six sections and two appendices, as summarized in Table 7.

Table 7 Essential Features of the Design Standard for Energy Efficiency in Residential Buildings in the Hot Summer and Warm Winter Zone (2003)

\begin{tabular}{|c|c|}
\hline Section Number and Title & Description \\
\hline 1. General Provisions & Purpose and scope \\
\hline 2. Terminology & Definition of the key terms used in this code \\
\hline $\begin{array}{l}\text { 3. Design Indices for Building Energy } \\
\text { Efficiency }\end{array}$ & $\begin{array}{l}\text { Two sub regions in the HSWW zone, recommended } \\
\text { indoor design temperature and outside air } \\
\text { ventilation rates }\end{array}$ \\
\hline 4. Envelope & $\begin{array}{l}\text { Mandatory and voluntary provisions related to } \\
\text { building envelopes }\end{array}$ \\
\hline $\begin{array}{l}\text { 5. Overall Evaluation of Building Energy } \\
\text { Efficiency Design }\end{array}$ & $\begin{array}{l}\text { Parameters used in the calculation of the whole } \\
\text { building energy conservation index and reference } \\
\text { building }\end{array}$ \\
\hline $\begin{array}{l}\text { 6. Heating, Ventilation and Air } \\
\text { Conditioning }\end{array}$ & Mandatory provisions and prescriptive criteria \\
\hline $\begin{array}{l}\text { Appendix A - Simplified Calculation } \\
\text { Method for Exterior Shading Coefficient }\end{array}$ & $\begin{array}{l}\text { Method and equations for calculating building } \\
\text { exterior shading coefficients in summer and winter }\end{array}$ \\
\hline $\begin{array}{l}\text { Appendix B - Simplified Calculation } \\
\text { Method of Annual Electricity } \\
\text { Consumption for Air Conditioning and } \\
\text { Heating }\end{array}$ & Calculation equations \\
\hline
\end{tabular}

Source: Design Standard for Energy Efficiency in Residential Buildings in the Hot Summer and Warm Winter Zone 2003

The HSWW zone is divided into two sub regions: the north sub region (for both cooling and heating) and the south sub region (for cooling only), presented in Figure 3.

${ }^{13}$ See $\S 4.0 .4, \S 4.0 .5, \S 4.0 .6, \S 4.0 .7, \S 4.0 .11, \S 4.0 .11, \S 6.0 .2$, and $\S 6.0 .6$. 
Figure 3 North and South Sub Regions in the Hot Summer and Warm Winter Zone

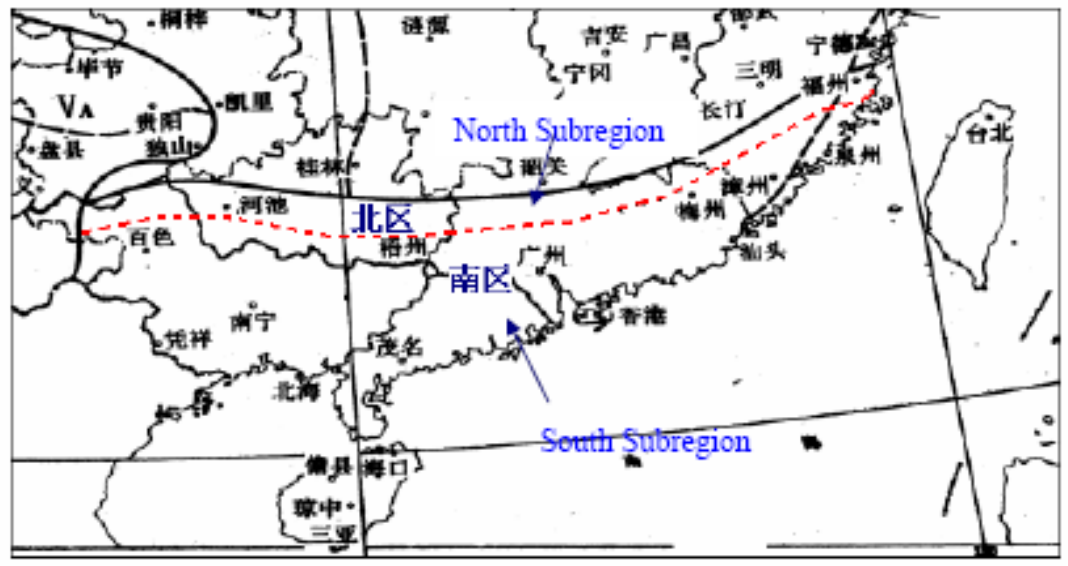

Notes: The red dotted line depicts the boundary between the north and south sub regions.

Source: Design Standard for Energy Efficiency in Residential Buildings in the Hot

Summer and Warm Winter Zone 2003

The area of exterior windows should not exceed the maximum WWR by orientation as follows: the WWR for windows facing north shall be less than 0.45 , east and west less than 0.30 , and south less than 0.50 . The U-factors (U) and thermal inertia indices (D) of a proposed design building should comply with the values presented in Table 8. Otherwise, the annual electricity consumption for air conditioning and heating should not surpass the value of the reference building.

Table 8 U-Factor (Watts $\left./ \mathbf{m}^{2} \cdot \mathbf{K}\right)$ and Thermal Inertia Index

\begin{tabular}{|c|c|}
\hline Roof & Exterior Wall \\
\hline $\mathrm{U} \leq 1.0, \mathrm{D} \geq 2.5$ & $\mathrm{U} \leq 2.0, \mathrm{D} \geq 3.0$ or $\mathrm{U} \leq 1.5, \mathrm{D} \geq 3.0$ or $\mathrm{U} \leq 1.0, \mathrm{D} \geq 2.5$ \\
\hline $\mathrm{U} \leq 0.5$ & $\mathrm{U} \leq 0.7$ \\
\hline
\end{tabular}

Source: Design Standard for Energy Efficiency in Residential Buildings in the Hot Summer and Warm Winter Zone 2003

Skylights proposed in a building design should not exceed $4 \%$ of the total roof area. Their U-factors and shading coefficients should be less than 4 watts $/ \mathrm{m}^{2} \cdot \mathrm{K}$ and 0.5 , respectively. Otherwise, the annual electricity consumption for air conditioning and heating should not surpass that of reference building.

The U-factor of exterior windows and the shading coefficients of a building design should comply with the values presented in Tables 6 and 7. Otherwise, the annual electricity consumption for air conditioning and heating should not surpass that of the reference building. 
Table 9 U-Factors and Overall Shading Coefficients of Exterior Window in the North Sub Region

\begin{tabular}{|c|c|c|c|c|c|c|}
\hline \multirow{2}{*}{$\begin{array}{l}\text { Exterior } \\
\text { wall }\end{array}$} & \multirow{2}{*}{$\begin{array}{c}\text { Overall Shading } \\
\text { Coefficient of } \\
\text { Window } \\
\end{array}$} & \multicolumn{5}{|c|}{ Thermal Transmission Coefficient of Exterior Windows } \\
\hline & & $\mathbf{W W R} \leq \mathbf{0 . 2 5}$ & $0.25<\mathbf{W W R} \leq \mathbf{0 . 3}$ & $0.3<W W R \leq 0.35$ & $0.35<W W R \leq 0.4$ & $0.4<W W R \leq 0.45$ \\
\hline \multirow{8}{*}{$\begin{array}{c}\mathrm{U} \leq 2.0 \\
\mathrm{D} \geq 3.0\end{array}$} & 0.9 & $\leq 2.0$ & - & - & - & - \\
\hline & 0.8 & $\leq 2.5$ & - & - & - & - \\
\hline & 0.7 & $\leq 3.0$ & $\leq 2.0$ & $\leq 2.0$ & - & - \\
\hline & 0.6 & $\leq 3.0$ & $\leq 2.5$ & $\leq 2.5$ & $\leq 2.0$ & - \\
\hline & 0.5 & $\leq 3.5$ & $\leq 2.5$ & $\leq 2.5$ & $\leq 2.0$ & $\leq 2.0$ \\
\hline & 0.4 & $\leq 3.5$ & $\leq 3.0$ & $\leq 3.0$ & $\leq 2.5$ & $\leq 2.5$ \\
\hline & 0.3 & $\leq 4.0$ & $\leq 3.0$ & $\leq 3.0$ & $\leq 2.5$ & $\leq 2.5$ \\
\hline & 0.2 & $\leq 4.0$ & $\leq 3.5$ & $\leq 3.0$ & $\leq 3.0$ & $\leq 3.0$ \\
\hline \multirow{7}{*}{$\begin{array}{c}\mathrm{U} \leq 1.5 \\
\mathrm{D} \geq 3.0\end{array}$} & 0.9 & $\leq 5.0$ & $\leq 3.5$ & $\leq 2.5$ & - & - \\
\hline & 0.8 & $\leq 5.5$ & $\leq 4.0$ & $\leq 3.0$ & $\leq 2.0$ & - \\
\hline & 0.7 & $\leq 6.0$ & $\leq 4.5$ & $\leq 3.5$ & $\leq 2.5$ & $\leq 2.0$ \\
\hline & 0.6 & $\leq 6.5$ & $\leq 5.0$ & $\leq 4.0$ & $\leq 3.0$ & $\leq 3.0$ \\
\hline & 0.4 & $\leq 6.5$ & $\leq 5.5$ & $\leq 4.5$ & $\leq 4.0$ & $\leq 3.5$ \\
\hline & 0.3 & $\leq 6.5$ & $\leq 5.5$ & $\leq 5.0$ & $\leq 4.0$ & $\leq 4.0$ \\
\hline & 0.2 & $\leq 6.5$ & $\leq 6.0$ & $\leq 5.0$ & $\leq 4.0$ & $\leq 4.0$ \\
\hline \multirow{8}{*}{$\begin{array}{c}\mathrm{U} \leq 1.0 \\
\mathrm{D} \geq 2.5, \text { or } \\
\mathrm{U} \leq 0.7\end{array}$} & 0.9 & $\leq 6.5$ & $\leq 6.5$ & $\leq 4.0$ & $\leq 2.5$ & - \\
\hline & 0.8 & $\leq 6.5$ & $\leq 6.5$ & $\leq 5.0$ & $\leq 3.5$ & $\leq 2.5$ \\
\hline & 0.7 & $\leq 6.5$ & $\leq 6.5$ & $\leq 5.5$ & $\leq 4.5$ & $\leq 3.5$ \\
\hline & 0.6 & $\leq 6.5$ & $\leq 6.5$ & $\leq 6.0$ & $\leq 5.0$ & $\leq 4.0$ \\
\hline & 0.5 & $\leq 6.5$ & $\leq 6.5$ & $\leq 6.5$ & $\leq 5.0$ & $\leq 4.5$ \\
\hline & 0.4 & $\leq 6.5$ & $\leq 6.5$ & $\leq 6.5$ & $\leq 5.5$ & $\leq 5.0$ \\
\hline & 0.3 & $\leq 6.5$ & $\leq 6.5$ & $\leq 6.5$ & $\leq 5.5$ & $\leq 5.0$ \\
\hline & 0.2 & $\leq 6.5$ & $\leq 6.5$ & $\leq 6.5$ & $\leq 6.0$ & $\leq 5.5$ \\
\hline
\end{tabular}

Source: Design Standard for Energy Efficiency in Residential Buildings in the Hot Summer and Warm Winter Zone 2003 
Table 10 Overall Shading Coefficients of Exterior Windows by Wall Characteristics in the South Sub Region

\begin{tabular}{|l|c|c|c|c|c|}
\hline \multirow{2}{*}{ Exterior wall } & \multicolumn{5}{|c|}{ Thermal transmission coefficient of exterior windows } \\
\cline { 2 - 6 } & $\begin{array}{c}\mathrm{WWR} \leq \\
0.25\end{array}$ & $0.25<\mathrm{WWR} \leq 0.3$ & $0.3<\mathrm{WWR} \leq 0.35$ & $\begin{array}{c}0.35<\mathrm{WWR} \\
\leq 0.4\end{array}$ & $0.4<\mathrm{WWR} \leq 0.45$ \\
\hline $\mathrm{U} \leq 2.0, \mathrm{D} \geq 3.0$ & $\leq 0.6$ & $\leq 0.5$ & $\leq 0.4$ & $\leq 0.4$ & $\leq 0.3$ \\
\hline $\mathrm{U} \leq 1.5, \mathrm{D} \geq 3.0$ & $\leq 0.8$ & $\leq 0.7$ & $\leq 0.6$ & $\leq 0.5$ & $\leq 0.4$ \\
\hline $\begin{array}{l}\mathrm{U} \leq 1.0, \mathrm{D} \geq 2.5, \\
\text { or } \mathrm{U} \leq 0.7\end{array}$ & $\leq 0.9$ & $\leq 0.8$ & $\leq 0.7$ & $\leq 0.6$ & $\leq 0.5$ \\
\hline
\end{tabular}

Source: Design Standard for Energy Efficiency in Residential Buildings in the Hot Summer and Warm Winter Zone 2003

\subsection{Standard for Lighting Design in Buildings (2004)}

Lighting is not part of China's design standards for energy efficiency in public and residential buildings, which are focused on the building envelope and HVAC. China issued the Standard for Lighting Design in Buildings in 2004; this standard covers energy efficiency design issues for lighting in residential, commercial and industrial buildings (Table 11).

Table 11 Essential Features of the Standard for Lighting Design in Buildings (2004)

\begin{tabular}{|l|l|}
\hline \multicolumn{1}{|c|}{ Section Number and Title } & \multicolumn{1}{c|}{ Description } \\
\hline 1. General Provisions & Purpose and scope \\
\hline 2. Terminology & Definition of key terms used in this code \\
\hline 3. General Rules & $\begin{array}{l}\text { Lighting types, selection of lighting sources and } \\
\text { evaluation of energy efficient lighting }\end{array}$ \\
\hline 4. Lighting Quantity and Quality & $\begin{array}{l}\text { Luminance, glare limitation, color of lighting } \\
\text { source and reflectance }\end{array}$ \\
\hline 5. Standard Values for Lighting & $\begin{array}{l}\text { Provisions on reference height above working } \\
\text { surfaces, and standard luminance for residential, } \\
\text { commercial and industrial buildings }\end{array}$ \\
\hline 6. Energy Efficient Lighting & $\begin{array}{l}\text { Provisions on lighting power density and } \\
\text { utilization of natural lighting }\end{array}$ \\
\hline 7. Distribution and Control & $\begin{array}{l}\text { Provisions for power distribution and lighting } \\
\text { controls }\end{array}$ \\
\hline 8. Administration & $\begin{array}{l}\text { Maintenance, implementation and monitoring } \\
\text { management }\end{array}$ \\
\hline Appendix A - Unified Glare Rating & \\
\hline Appendix B - Glare Rating & Source: Standard for Lighting Design in Buildings 2004
\end{tabular}

Lighting power density (LPD) is employed as the key indicator for the assessment of lighting energy efficiency. The standard provides maximum current and target LPDs for residential (voluntary), commercial (mandatory) and industrial (mandatory) buildings.

The maximum LPDs for office buildings are presented in Table 11. The current values refer to the values required or recommended by the lighting standard, and the target 
values are the values to be in use in accordance with the decision of the related administrative agencies. For example, the current and target LPDs for offices (general) are 11 and 9 watts $/ \mathrm{m}^{2}$, respectively. The current and target LPDs for residential buildings (living room, bedroom, dinning room, kitchen and bathroom) are 7 and $8 \mathrm{watts} / \mathrm{m}^{2}$, respectively.

Table 12 Maximum Lighting Power Densities for Office Buildings Unit: watt $/ \mathrm{m}^{2}$

\begin{tabular}{|l|c|c|}
\hline & Current Values & Target Values \\
\hline Office (general) & 11 & 9 \\
\hline High-class office, design office & 18 & 15 \\
\hline Meeting room, copy and mail room & 11 & 9 \\
\hline Documentation room & 8 & 7 \\
\hline
\end{tabular}

Source: Standard for Lighting Design in Buildings 2004

\section{Other Developments}

\subsection{A Brief Review}

Since 2004, MOHURD has issued a series of regulations, policies and programs to promote building energy efficiency, including:

- Management of Energy Conservation Pilot Projects (2004),

- National Green Building Innovation Awards (2004, 2005, 2006, 2007),

- Notice on Enforcement of Building Energy Standards for New Residential Buildings (2005),

- Notice on Conducting Building Energy Conservation Inspections (2005, 2006),

- Green Building Technology Guidance (2005),

- Management of Energy Conservation in Civic Buildings (2005),

- Notice on Central Governmental Activities in the Energy Conservation Week (2006),

- Pilot Projects for Renewable Energy in Buildings (2005, 2006, 2007),

- Guidance on Building Energy Efficiency Evaluations and Labeling (2006),

- Civic Building Energy Consumption Statistics Reporting (trial) (2007),

- Guidance on Energy Audits for Governmental Buildings and Large-scale Public Buildings (2007),

- Green Building Evaluation Labeling (2008), and

- Management and Technical Guidance for Energy-efficient Campuses in Universities and Colleges (2008).

The government developed the Green Olympic Building Assessment System (GOBAS) to evaluate the environmental qualities of buildings for the 2008 Olympics. 


\subsection{Green Building Evaluation Standard}

MOHURD released China's first green building standard in 2006, the Green Building Evaluation Standard, which is viewed as a counterpart to LEED in China.

The standard covers (1) land conservation, (2) energy conservation, (3) water conservation, (4) material conservation, (5) indoor environmental quality, and (6) operation and management throughout the life cycle of residential and public buildings. Each section contains control items (requirements), recommended, general items and preferred items.

Since 2006, MOHURD has developed a series of regulations and programs to promote green buildings, such as the Green Building Demonstration Projects (2007) and Green Building Evaluation Labeling (2008).

\subsection{The Regulations on Energy Conservation in Civil Buildings}

The State Council issued the Regulations on Energy Conservation in Civil Buildings, developed by MOHURD, in October 2008. This was a recent governmental effort to promote building energy efficiency in residential and public buildings.

Compliance with building energy codes is one of the contents underscored in the Regulations. The Regulations clarify the national and local administrative roles in promoting building energy efficiency, and specify the responsibilities of designers, builders, inspectors and the legal consequences of violating the regulations.

The Regulations also call for the compliance with building energy codes, heat supply reform laws, local building energy conservation fund, coordination of financing for existing buildings, promotion of solar and other renewable energy, and leadership of governmental buildings in energy conservation.

\section{Conclusions}

Among APP countries, China is one of the earliest developers of national building energy codes (1986), after the United States (1975) and Japan (1985).

Currently, China has one national code for public buildings (published in 2005), and three residential buildings codes in the heating zone (published in 1986 and revised in 1995), the HSCW zone (published in 2001) and the HSWW zone (published in 2003). The standards include both mandatory and recommended provisions.

China's current building energy codes in both public and residential buildings are mainly focused on the building envelope and HVAC systems, excluding other important building components such as lighting, electric power and hot water systems. There are separate energy standards for lighting, room air conditioners and commercial HVAC. 
The Chinese government's priorities for developing the building energy codes are from northern to the southern part of China, from residential to public buildings, and from new to existing buildings. For example, A new standard named the Technical Specifications for the Energy Efficient Renovation of Existing Public Buildings is in the approval process already, and the Technical Specifications for the Energy Efficient Renovation of Existing Residential Buildings in the Heating Zones (2001) is being updated and will change its name to reflect that it covers existing residential buildings in all climate zones.

Building energy code compliance and enforcement have been problematic. In recent years, the Chinese government has demonstrated a clear commitment to improving building energy efficiency by issuing a series of regulations, policies and programs, such as conducting national and provincial surveys of building energy efficiency. With the strong determination of the Chinese government and broad international collaboration, China has a great opportunity to positively shape global building energy use in coming years. 


\section{List of Acronyms}

APP Asia-Pacific Partnership on Clean Development and Climate

ASHRAE American Society of Heating, Refrigerating and Air-Conditioning Engineers

BATF Buildings Appliance Task Force (of the APP)

CABR China Academy of Building Research

CDD Cooling degree day (cooling degree days are like heating degree days, however they are calculated only for days where outdoor temperature exceeds a certain temperature).

D Thermal inertia index

EIA Energy Information Administration (U.S. Department of Energy)

GDP Gross domestic product

GOBAS Green Olympic Building Assessment System

HDD Heating degree day (heating degree days are calculated according to the Indoor temperature used as the baseline for calculation, e.g., HDD18 if the baseline temperature is $18^{\circ} \mathrm{C}$ ).

HSCW Hot summer and cold winter

HSWW Hot summer and warm winter

HVAC Heating, ventilation and air conditioning

IEA International Energy Agency

IMF International Monetary Fund (United Nations)

LPD Lighting power density

MOHURD Ministry of Housing and Urban-Rural Development

Mtoe Million tons of oil equivalent

NDRC National Development and Reform Commission

OECD Organisation for Economic Co-operation and Development

PPP Purchasing power parity

R\&D Research and development

SC Shading coefficient

U U-factor

VLT Visual light transmittance

WWR Window-to-wall ratio 


\section{References}

1. CABRa. 2008. Submission Report for the Design Standard for Energy Efficiency in Residential Buildings in the Hot Summer and Cold Winter Zone. Beijing: China Academy of Building Research.

2. CABRb. 2008. Submission Report for the Design Standard for Energy Efficiency in Residential Buildings in the Sever Cold and Cold Zone. Beijing: China Academy of Building Research.

3. EIA. 2009. World Carbon Dioxide Emissions from the Consumption and Flaring of Fossil Fuels 2008 [cited January 2009]. Available from www.eia.doe.gov/emeu/international/carbondioxide.html (Accessed).

4. Huang, Joe, and Joe Deringer. 2008. Energy Efficiency Building Standards in China 2007 [cited September 2008]. Available from www.asiabusinesscouncil.org/docs/BEE/papers/BEE_Policy_China.pdf (Accessed).

5. IEA. 2007. Energy Balances of Non-OECD Countries (2007 edition).

6. IMF. 2009. World Economic Outlook Databases. International Monetary Fund 2008 [cited January 2009]. Available from www.imf.org/external/ns/cs.aspx?id=2.

7. Lang, Siwei. 2005. Energy Efficiency Requirements for Cooling and Heating Sources in GB50189-2005 Design Guide for Energy Efficiency in Public Buildings. China Construction Heating \& Refrigeration 7.

8. Lin, Haiyan. 2008. A Brief Introduction to the Chinese Design Standards for Energy Efficiency in Residential Buildings. Beijing: China Academy of Building Research.

9. MOHURD. 2005. Guidelines for Developing Energy and Land Conservation in Residential Buildings and Public Buildings. Beijing: Ministry of Housing and UrbanRural Development.

10. Wu, Yong, and Changbin Liu. 2007. Policy Study on China Building Energy Incentive Program. Beijing: China Construction Industry Publishing House.

11. Wu, Yong, Changbin Liu, Yingzong Liu, and Hongle Qu. 2007. Study on China Building Energy Management System. Beijing: China Construction Industry Publishing House.

\section{Useful Websites}

1. China Academy of Building Research, www.cabr.ac.cn/engweb/index.htm

2. National Development and Reform Commission, http://en.ndrc.gov.cn/ 



\section{The Asia-Pacific Partnership on Clean Development and Climate}

The Asia-Pacific Partnership on Clean Development and Climate is an innovative new effort to accelerate the development and deployment of clean energy technologies.

\section{Partner Countries}

APP partners Australia, Canada, China, India, Japan, Republic of Korea, and the United States have agreed to work together and with private sector partners to meet goals for energy security, national air pollution reduction, and climate change in ways that promote sustainable economic growth and poverty reduction. The Partnership will focus on expanding investment and trade in cleaner energy technologies, goods and services in key market sectors. The Partners have approved eight public-private sector task forces covering:

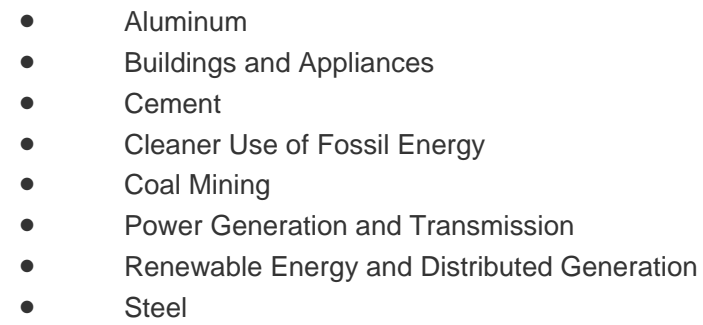

The seven partner countries collectively account for more than half of the world's economy, population and energy use, and they produce about 65 percent of the world's coal, 62 percent of the world's cement, 52 percent of world's aluminum, and more than 60 percent of the world's steel.

\section{Buildings and Appliances Task Force}

Reducing our use of energy for buildings and appliances decreases the demand for primary energy and is a key means to deliver better economic performance, increase energy security and reduce greenhouse gas and air pollutant emissions. Partner countries have recognized for some time the importance of cooperating on energy efficiency for buildings and appliances, and have already taken a range of bilateral and other collaborative actions in this area. As the Partners represent a majority of the world's manufacturing capacity for a diverse range of appliances, we have the potential to drive significant regional and global improvements in energy efficiency in this sector. The Partners will demonstrate technologies, enhance and exchange skills relating to energy efficiency auditing, share experiences and policies on best practices with regard to standards and codes, as well as labeling schemes for buildings, building materials and appliances. 


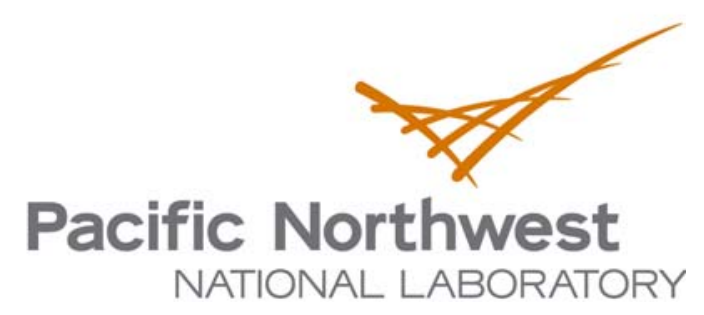

